\title{
Post-radioiodine management of patients with Graves' disease
}

\author{
K Collins, , P Perros, J Horsefield \\ From International Conference for Healthcare and Medical Students 2011 \\ Dublin, Ireland. 4-5 November 2011
}

\begin{abstract}
Introduction
Radioiodine is a safe and effective treatment for Graves' disease. Iatrogenic hypothyroidism is very common after treatment, but its onset is unpredictable. Even a short episode of hypothyroidism can result in significant morbidity and ideally should be avoided. In Newcastle a standard dose of radioiodine $(400 \mathrm{MBq})$ is used, but for historical reasons two different protocols are used after radioiodine: Regimen A: regular clinical and biochemical monitoring and initiation of levothyroxine when serum thyroid hormones have normalized, and Regimen B: block and replace with Carbimazole and levothyroxine starting 2 weeks post-radioiodine and continuing for 6 months, then withdrawing Carbimazole, but continuing with levothyroxine long-term.
\end{abstract}

\section{Methods}

The objective was to compare the two protocols for incidence of biochemical and clinical hypothyroidism during a 12 month post-radioiodine follow-up period and effects on weight gain and development or progression of orbitopathy. Patients with Graves' disease who were treated between January 2008-December 2009 were included. The medical records were reviewed and data were collected and analyzed.

\section{Results}

One hundred and twenty two patients were studied, 78 treated with Regimen A and 43 with Regimen B. Euthyroidism at 8 weeks, 6 months and 12 months post-radioiodine was achieved in $50 \%, 64 \%$ and $73 \%$ of patients with Regimen $A$ and $65.1 \%, 71 \%$ and $65 \%$ in patients with regimen B respectively. Clinical hypothyroidism during follow-up was commoner in Regimen A than B $(52.6 \%$ vs $16.3 \%$ respectively, $\mathrm{p}<0.05$ ). Weight gain was reported more frequently

\footnotetext{
Departments of Endocrinology and Medical Physics, Royal Victoria Infirmary,
} Newcastle upon Tyne, UK

C 2012 Collins et al; licensee BioMed Central Ltd. This is an Open Access article distributed under the terms of the Creative Commons Attribution License (http://creativecommons.org/licenses/by/2.0), which permits unrestricted use, distribution, and reproduction in any medium, provided the original work is properly cited. in Regimen A than B (43.6\% vs $20.9 \%, \mathrm{p}<0.05)$. The incidence of new Graves' orbitopathy developing after radioiodine was higher in Regimen A than B (11.1\% vs 5.3\%).

\section{Conclusions}

A 6 month course of block and replace followed by levothyroxine after a standard $400 \mathrm{MBq}$ dose of radioiodine is associated with better clinical outcomes than a watchful approach and initiation of levothyroxine based on biochemical and clinical indicators.

Published: 9 July 2012

doi:10.1186/1753-6561-6-S4-O37

Cite this article as: Collins et al:: Post-radioiodine management of patients with Graves' disease. BMC Proceedings 2012 6(Suppl 4):O37.

Submit your next manuscript to BioMed Central and take full advantage of:

- Convenient online submission

- Thorough peer review

- No space constraints or color figure charges

- Immediate publication on acceptance

- Inclusion in PubMed, CAS, Scopus and Google Scholar

- Research which is freely available for redistribution 